\title{
Program Konseling Kelompok Bagi Pendamping P2TP2A Aceh Utara Pada Masa Pandemi Covid-19
}

\section{Group Counseling Program for P2TP2A North Aceh Paralegal During Covid-19 Pandemic}

\author{
Ella Suzanna ${ }^{\left(1^{*}\right)}$, Ika Amalia( ${ }^{(2)} \&$ Cut Ita Zahara(3) \\ Program Studi Psikologi, Fakultas Kedokteran, Universitas Malikussaleh, Indonesia \\ Disubmit: 06 Desember 2020; Diproses: 21 Desember 2020; Diaccept: 01 Agustus 2021; Dipublish: 02 Agustus 2021 \\ *Corresponding author: E-mail: ellasuzanna@unimal.ac.id
}

\begin{abstract}
Abstrak
Selama masa Pandemi Covid-19, kegiatan pendampingan kasus oleh Pusat Pelayanan Terpadu Pemberdayaan Perempuan dan Anak (P2TP2A) di Aceh Utara tetap dilakukan seperti pada masa sebelum pandemi, namun tetap mengikuti protokol Covid-19. Banyak dari pendamping yang memiliki tingkat kecemasan yang tinggi karena takut tertular covid ketika menjalankan tugas. Hal ini dikarenakan sebagian klien yang mereka dampingi tidak mengikuti protokol Covid-19, seperti tidak menjaga jarak, tidak menggunakan masker ketika berinteraksi, tidak mencuci tangan, dan bersentuhan dengan orang lain. Oleh karena itu, penting dilakukan kegiatan konseling kelompok bagi para pendamping perempuan dan anak korban kekerasan ini, yaitu dengan tujuan mendapatkan gambaran psikologis pendamping secara menyeluruh terkait aspek kognitif, afektif, dan psikomotornya. Kemudian, konseling kelompok juga bertujuan agar pendamping dapat menemukan metode coping yang tepat dan sesuai untuk mengurangi kecemasan dan depresi yang mereka alami. Program ini dilaksanakan melalui empat tahap; pengumpulan data awal (asesmen), psikoedukasi, konseling, dan evaluasi. Hasilnya adalah para pendamping mengetahui dengan jelas mengenai permasalahan psikologis yang mereka alami, memahami resource (sumberdaya) yang mereka miliki dan berhasil menemukan strategi coping yang tepat untuk mengatasi kecemasan. Rekomendasi dari kegiatan ini adalah agar dirancang program serupa secara kontinyu, misalnya dibentuk support group di kalangan pendamping muda P2TP2A yang melakukan kegiatan konseling kelompok rutin setiap bulan. Hal ini bertujuan agar pendamping tidak merasa jenuh dengan pekerjaan mereka karena harus berhadapan dengan kasus-kasus berat setiap harinya.
\end{abstract}

Kata Kunci: Kecemasan; Konseling Kelompok; Pandemi Covid-19; Pendamping P2TP2A.

\begin{abstract}
During the Covid-19 Pandemic, case assistance by the Integrated Service Center for the Empowerment of Women and Children (P2TP2A) in North Aceh were still carried out as in the pre-pandemic time. Many of the paralegal feel anxious of covid-19 while carrying out their duties, because most of the clients they assisst do not follow the Covid-19 protocol, such as not commit to physical distancing, not using masks when interacting, not washing their hands, and often doing physical contact with other people. Therefore, it is important to carry out group counseling for the paralegal to obtain a comprehensive psychological picture of the paralegal regarding their cognitive, affective, and psychomotor aspects. Furthermore, group counseling also aims to help the paralegal finds an appropriate coping methods to reduce their symptoms of anxiety and depression. This program is implemented in four stages; initial data collection (assessment), psychoeducation, counseling, and evaluation. The result is that the paralegals know clearly about the psychological problems they experience, understand the resources they have and are able to find the right coping strategy to overcome their anxiety. The recommendation for the next activity is to design a similar program such as a support groups system among P2TP2A paralegals who will do routine group counseling activities every month. The aim is to make paralegal does not feel bored with their work because of serious cases they face every day. Keywords: Anxiety; Covid-19 Pandemic; Group Counseling; P2TP2A Paralegal.
\end{abstract}

DOI: https://doi.org/10.51849/j-p3k.v2i2.74

\section{Rekomendasi mensitasi :}

Suzzana, E., Amalia, I., \& Zahara, C.I. (2021), Program Konseling Kelompok Bagi Pendamping P2TP2A Aceh Utara Pada Masa Pandemi Covid-19 . Jurnal Penelitian Pendidikan, Psikologi dan Kesehatan (J-P3K), 2 (2): 174181. 


\section{PENDAHULUAN}

Pusat

Pelayanan

Terpadu

Pemberdayaan Perempuan dan Anak (P2TP2A) adalah pusat pelayanan yang dibentuk oleh pemerintah atau berbasis masyarakat yang menyeluruh dalam upaya perlindungan perempuan dan anak dari segala bentuk tindak kekerasan, diskriminasi, dan perdagangan orang, serta pemberdayaan perempuan di berbagai bidang pembangunan (Permen PPPA RI, 2015). Bentuk kegiatan dan programnya dapat berupa: pusat rujukan, pusat konsultasi usaha, pusat konsultasi kesehatan reproduksi, pusat konsultasi hukum, pusat krisis terpadu (PKT), pusat pelayanan terpadu (PPT), pusat pemulihan trauma (trauma center), pusat penanganan krisis perempuan (women crisis center), pusat pelatihan, pusat informasi ilmu pengetahuan dan teknologi (PIPTEK), rumah aman (shelter), rumah singgah, atau bentuk lainnya (p2tp2a.acehprov.go.id)

Untuk Kabupaten Aceh Utara sendiri, P2TP2A banyak sekali menerima laporan mengenai kasus kekerasan terhadap perempuan dan anak. Berdasarkan data dari Ellyati (2019) yang menjabat sebagai Kepala P2TP2A Aceh Utara, selama tahun 2019 P2TP2A Aceh Utara menangani sejumlah total 109 kasus kekerasan terhadap perempuan dan anak yang terdiri dari 57 kasus kekerasan dalam rumah tangga (KDRT), dan 52 kasus kekerasan seksual. Kasus kekerasan seksual yang ditangani ini dibagi lagi menjadi tiga kategori; 34 kasus kekerasan seksual terhadap anak, dan sebanyak 18 kasus kekerasan dan pelecehan seksual pada perempuan dewasa. Dalam proses penanganannya, tidak semua kasus selesai secara hukum, banyak juga yang tidak selesai secara hukum dan masih perlu pendampingan secara intensif, serta juga proses mediasi kekeluargaan antara pihak korban dan pelaku. Disinilah peran penting pendamping P2TP2A. Para pendamping bertugas untuk memberikan layanan dan pendampingan psikologis serta konseling pada klien sesuai dengan kebutuhannya. Kemudian ada kunjungan rumah (home visit) juga untuk mendapatkan informasi mengenai kasus yang ditangani secara lengkap. Untuk kasus-kasus tertentu, pendamping juga harus menemani korban untuk melakukan visum di rumah sakit.

Selama masa Pandemi Covid-19, kegiatan pendampingan kasus tetap dilakukan seperti pada masa sebelum pandemi, namun lebih diutamakan hanya pada kasus-kasus emergency saja. Biasanya pendamping menemani korban jika korban harus divisum di rumah sakit, namun karena kondisi pandemi, pendamping hanya menemani korban dalam hal mengurus kelengkapan administrasi. Namun, untuk kasus-kasus tertentu yang sifatnya emergency, terkadang pendamping harus masuk ke dalam ruangan korban yang merupakan pasien rawat inap.

Berdasarkan wawancara awal dengan beberapa pendamping muda, didapatkan informasi bahwa selama masa pandemi Covid-19 ini, pendamping muda merasa lebih cemas dan khawatir. Jika dulunya hanya khawatir dengan ancaman dari pelaku kekerasan, sekarang ditambah lagi merasa khawatir dengan ancaman wabah penyakit Covid-19. Karena 
kebanyakan dari korban dan keluarga korban yang didampingi oleh mereka tidak mengikuti protokol waspada dan pencegahan Covid-19, seperti tidak menggunakan masker ketika berbicara atau bertemu dengan pendamping, tidak mencuci tangan, tidak menjaga jarak, dan tetap bersalaman seperti biasa. Para pendamping juga tidak mengetahui dengan jelas bagaimana kondisi korban, apakah korban negatif atau positif Covid, dan hal ini juga membuat khawatir para pendamping muda dalam bertugas.

Selain hal yang disebut di atas, ketika wawancara awal, salah satu pendamping juga menyebutkan, pada proses pendampingan kasus ada hal-hal yang berbeda dari masa pandemi, misalnya pada saat dulu pendamping dapat merangkul, memberi support lewat sentuhan ataupun pelukan untuk korban perempuan. Namun, pada masa pandemi ini, gerakan mereka menjadi sangat terbatas, pendampingan dilakukan dengan jarak minimal satu meter, harus menggunakan masker ketika berbicara, dan waktu berbicara yang dibatasi.

Pada masa pandemi Covid-19 ini, pendamping P2TP2A banyak juga yang mengalami kecemasan, was-was, khawatir, dan takut ketika harus tetap bekerja di lapangan, bertemu klien, dan mendampingi klien hingga kasus selesai. Apabila perasaan cemas, was-was, khawatir dan takut ini tidak bisa dikelola dengan baik dan dibiarkan begitu saja, maka lama-kelamaan akan dapat menjadi gangguan yang akan lebih sulit untuk disembuhkan (Ridlo, 2020).

Berdasarkan uraian diatas, kami sebagai konselor dan psikolog merasa perlu membuat sebuah kegiatan pengabdian kepada masyarakat untuk menjawab permasalahan para pendamping muda di P2TP2A Aceh Utara. Program yang akan dilaksanakan dalam pengabdian masyarakat ini adalah program psikoedukasi dan konseling. Psikoedukasi merupakan sebuah penyuluhan dalam bidang psikologi yang menjelaskan mengenai suatu materi tertentu, dalam hal ini yaitu mengenai Covid-19, penyebarannya dan pencegahannya, serta dampak-dampak psikologis yang muncul baik jangka pendek maupun jangka panjang (Dewi, 2012). Sedangkan program konseling yaitu kegiatan pemulihan kondisi psikologis sehingga individu dapat kembali merasakan kenyamanan, kebahagiaan dan kesejahteraan psikologis dalam dirinya (Dewi, 2012). Maka, kegiatan pengabdian kepada masyarakat ini mengambil judul "Program Konseling Kelompok Bagi Pendamping Muda P2TP2A Aceh Utara Pada Masa Pandemi Covid-19".

\section{METODE PELAKSANAAN}

Kegiatan ini diawali dengan pegamatan terhadap fenomena pedamping yang bekerja di P2TP2A, dimana pendamping tetap melakukan pedampingan kasus di lapangan untuk membantu mendampingi korban KDRT, pelecehan seksual, dan penganiayaan, dalam situasi dan kondisi pandemi yang masih berlangsung. Untuk mengetahui bagaimana kondisi psikologis pedamping saat bekerja dalam situasi pandemi ini, para konselor mengawali dengan pendekatan personal kepada beberapa 
pedamping untuk mendapatkan informasi mengenai bagaimana keadaan psikologis pedamping bekerja dalam situasi pandemik.

Para konselor melakukan wawancara singkat, guna memperoleh gambaran mengenai kondisi psikologis pedamping selama bekerja dalam situasi pandemi. Berdasarkan hasil wawancara dengan pendamping, ditemukan beberapa gejala psikologis yang menganggu pedamping selama melakukan pedampingan di lapangan. Kemudian konselor menentukan tema pengabdian yang sesuai dengan kebutuhan pedamping.

Berdasarkan kondisi psikologis pedamping saat ini, hal yang dapat dilakukan yaitu mengadakan kegiatan konseling kelompok. Durasi waktu yang digunakan untuk kegiatan konseling kelompok ini adalah satu sampai dua jam per pertemuan, berkisar antara satu hingga tiga kali pertemuan. Frekuensi pertemuan adalah satu kali dalam dua minggu.

Metode pelaksanakan kegiatan konseling kelompok diberikan kepada pedamping P2TP2A kabupaten Aceh Utara. Bentuk kegiatan yang akan dilaksanakan mulai tanggal 1 September s/d 31 Oktober 2020, dengan deskripsi kegiatan sebagai berikut:

1. Pengumpulan data awal melalui observasi dan wawancara yang dilakukan kepada pendamping P2TP2A Aceh Utara.

2. Psikoedukasi tentang kesehatan mental diberikan kepada pedamping P2TP2A Aceh Utara, agar pedamping memiliki ilmu berdasarkan teori psikologi.
3. Konseling kelompok dilakukan mulai 728 September 2020 selama 4 kali pertemuan dengan durasi waktu 1-2 Jam per sesi.

4. Evaluasi Kegiatan.

\section{HASIL DAN PEMBAHASAN}

Pendamping atau paralegal harus tetap melakukan kegiatan pendampingan di masa pandemi covid-19 dengan menggunakan dua metode, melalui media online (whatsapp, telepon, sms, email, zoom) ataupun tatap muka. Kegiatan tatap muka dilakukan hanya untuk kasus-kasus yang bersifat darurat dan perlu penanganan segera. Pendampingan yang dilakukan di masa pandemi covid-19 tidaklah maksimal seperti pendampingan yang dilakukan sebelum masa pandemi covid-19. Pendamping atau paralegal pada masa mewabahnya covid-19 tetap melakukan pendampingan kasus, dengan memperhatikan protokol kesehatan. Namun pada kondisi pandemi ini, tidak semua masyarakat (terutama korban) patuh dan memperhatikan protokol kesehatan, mulai dari tidak menggunakan masker, tidak mencuci tangan dan tidak menjaga jarak. Tentunya hal ini membuat para pendamping atau paralegal merasa cemas dan khawatir akan terjangkit ataupun tertular Covid-19. Kondisi ini menambah beban psikologis bagi pendamping, disamping beban lainnya yang harus ditanggung, seperti ancaman, teror, intimidasi dari pelaku kekerasan yang kerap membatasi gerak langkah pendamping. Beban yang ditanggung pendamping tentunya mempengaruhi psikologis dalam kehidupan sehari-hari, di dalam rumah tangga, lingkungan dan 
komunitas. Pandemi ini memiliki dampak bukan hanya pada situasi politik dan ekonomi tapi juga kondisi jiwa masyarakat yang terdampak, sehingga mempengaruhi interaksi antar individu dan kelompok.

Berdasarkan angket kecemasan yang diberikan kepada 20 orang pedamping yang hadir di kegiatan di hari pertama, 14 diantaranya hanya mengalami stress dan tidak memiliki masalah dengan depresi, sedangkan enam orang lainnya mengalami stress dan juga memiliki simptomsimptom depresi. Pendamping yang mengalami simptom-simptom depresi yaitu terutama adalah pedamping yang memiliki banyak pengalaman dalam melakukan pedampingan kasus (usia pedampingan). Jadi, semakin tinggi pengalaman pedampingan semakin tinggi pula tingkat depresi yang dihadapi oleh pendamping.

Dari program konseling kelompok yang dilakukan dalam tiga tahap, didapatkan hasil sebagai berikut:

\section{Tahap pertama}

Pada tahap pertama ini, peserta diminta untuk mengungkapkan hal-hal apa saja yang menjadi kendala pada saat melakukan tugas sebagai pendamping perempuan dan anak korban kekerasan baik kekerasan seksual maupun kekerasan fisik dan verbal. Dari 20 pendamping yang hadir, semuanya memberikan opini tentang hal-hal yang menjadi kendala pada saat mereka melakukan tugasnya, terutama pada masa pandemi ini. Sebagian besar merasa terkendala dengan cara berkomunikasi dengan klien selama masa pandemi ini.
Karena cara berkomunikasi pada saat pandemi covid-19 ini sangat jauh berbeda dengan cara berkomunikasi pada saat situasi normal. Pada saat ini, mereka harus menjaga jarak, minimal satu meter dengan klien. Kemudian terkendala juga ketika akan memberikan penguatan afeksi seperti sentuhan fisik untuk menenangkan klien, hal tersebut tidak dapat dilakukan pada masa pandemi ini karena harus menjaga jarak. Kendala lainnya keterbatatasan bahasa nonverbal yang agak sulit direalisasikan oleh para pendamping ketika harus menjaga jarak (physical distancing) dengan klien. Kendala lainnya yang diungkapkan oleh pendamping adalah tidak dapat maksimal memberikan pendampingan ketika harus mendampingi klien di Rumah sakit untuk melakukan visum. Ketika situasi normal, pendamping dapat menemani klien secara full dari awal sampai selesai proses pemeriksaan fisik. Namun, pada saat pandemi, pendamping hanya boleh menemani klien pada saat proses melengkapi administrasi saja, sedangkan untuk masuk ke ruangan visum tidak diperbolehkan selama masa pandemi ini. Namun ada kasus-kasus dimana pendamping harus melakukan pendampingan maksimal terhadap korban dikarenakan kasus tersebut adalah kasus emergency yang butuh penanganan segera. Pada konseling tahap pertama ini hanya dilakukan pengumpulan data kendala-kendala yang dihadapi oleh pendamping, dan bagaimana cara pendamping menghadapi kendala-kendala tersebut. Hal ini penting dilakukan agar para pendamping memahami bahwa kendala-kendala tersebut tidak hanya 
dihadapi oleh satu atau dua orang saja, namun sebagian besar mengalaminya dan mereka bisa berbagi perasaan yang sama sehingga dapat menghadapi secara bersama-sama pula. Konseling kelompok tahap I ini berjalan dengan lancar dan ketika para peserta diminta untuk memberikan feedback terhadap kegiatan konseling tahap pertama ini, mereka memberikan pandangan positif. Konseling kelompok dilanjutkan ke tahap selanjutnya untuk membicarakan atau lebih fokus pada perasaan peserta.

\section{Tahap kedua}

Pada konseling kelompok tahap kedua ini, masalah yang dibicarakan adalah lebih fokus pada kondisi emosional para pendamping. Hampir semua pendamping menyatakan perasaan khawatir dan was-was dengan kondisi yang ada. Mereka menyatakan sebelum pandemi covid, mereka bisa berbagi pendampingan dengan teman-teman dan hampir merata, serta dapat beradaptasi langsung dengan korban. Mereka tidak memiliki rasa takut yang berlebihan, kecuali jika menghadapi ancaman dari pelaku kekerasan. Namun, pada situasi pandemi covid ini, pendamping merasa khawatir yang berlebihan terhadap klien yang cenderung tidak mematuhi protokol covid. Pendamping juga merasa was-was karena tidak mengenal klien dan tidak mengetahui dengan jelas apakah diantara klien ada yang positif covid atau tidak. Sebagian pendamping mengatakan bahwa mereka khawatir terkena covid karena harus berhadapan dengan banyak orang dan terkadang harus masuk ke ruangan rawat inap. Akibatnya, pendampingan lebih banyak dilakukan melaui telepon, dan mereka hanya dapat memberikan support melalui kata-kata saja. Sebagian besar pendamping juga mengatakan saat ini lebih banyak memiliki pikiran negatif saat bekerja daripada pikiran positif, sehingga hal tersebut berdampak pada kondisi psikologis mereka. Misalnya, mereka khawatir jika harus ke rumah sakit, karena menurut mereka Rumah Sakit merupakan tempat yang tidak aman dan merupakan sarang penyakit, dan mereka bisa saja terinfeksi virus sewaktuwaktu, dan hal ini membuat mereka tidak fokus dalam bekerja. Setelah semua pendamping mengungkapkan apa yang menjadi kekhawatiran dan keresahan mereka, peserta diminta untuk berbagi pengalaman mengenai strategi coping yang mereka lakukan untuk mengatasi kecemasan yang mereka alami. Kemudian, fasilitator mengajarkan teknik-teknik relaksasi untuk mengurangi kecemasan pada pendamping muda tersebut. Setelah itu, dilakukan evaluasi terhadap efektifitas intervensi yang dilakukan oleh para konselor. Hasilnya, peserta merasa lebih tenang dan relaks setelah diberikan teknik relaksasi tersebut.

\section{Tahap ketiga}

Pada tahap ketiga ini, konseling kelompok dilakukan dengan berfokus pada strategi coping atau penanganan masalah-masalah yang dihadapi oleh para pendamping. Selain strategi coping, konseling tahap ketiga ini mengungkapkan berbagai resource (sumber daya) yang menjadi penguat bagi pendamping sehingga dapat bertahan dalam situasi yang sulit. Peserta 
mengungkapkan selain hal negatif, ada juga hal-hal positif yang didapatkan selama mendampingi klien yang menjadi korban kekerasan. Diantaranya, pendamping jadi lebih menghargai keberadaan keluarganya, menjadi lebih bersyukur dengan apapun keadaan yang mereka alami, karena mereka merasa beban yang dialami oleh klien jauh lebih berat dibandingkan dengan beban yang mereka hadapi. Selain terkait masalah pandemi covid, hal lainnya yang menjadi permasalahan umum bagi pendamping adalah masalah penundaan menikah bagi pendamping muda yang masih single. Banyak dari mereka yang belum menikah dikarenakan merasa "trauma" dengan laki-laki yang umumnya menjadi pelaku kekerasan seksual. Hal itu terjadi karena mereka merasa terlalu berempati terhadap klien yang kebanyakan memang korban kekerasan seksual. Namun, hal itu membuat para pendamping lebih berhatihati dalam bergaul dengan laki-laki terutama dalam memilih pasangan hidup. Sebagian besar juga mengatakan dengan mendengar berbagai macam permasalahan hidup wanita-wanita yang menjadi korban kekerasan fisik, verbal dan seksual ini, mereka menjadi lebih dewasa dan mendapat berbagai pengalaman yang berharga. Hal inilah yang merupakan resource (sumber daya) bagi para pendamping wanita ini. Seluruh pendamping dalam konseling kelompok ini juga menyampaikan sangat beruntung karena bisa bergabung menjadi pendamping di P2TP2A Aceh Utara. Banyak pengalaman berharga yang mereka dapatkan. Mereka dapat lebih mengasah rasa empati dan dapat meningkatkan keahlian mendengarkan dan memahami orang lain. Salah satu contoh, ketika mendengarkan hasil keputusan sidang yang berpihak kepada korban, ada kelegaan di hati mereka walaupun hal tersebut belum sebanding dengan apa yang korban alami. Dari apa yang disampaikan peserta dalam konseling ini, program konseling kelompok ini memberikan banyak manfaat bagi pendamping. Diantaranya, mereka dapat berbagi pengalaman dan cerita dengan pendamping lainnya, mereka dapat melepaskan rasa sesak di dada akibat banyak sekali mendengarkan kisah-kisah hidup menyedihkan para perempuan korban kekerasan, dan yang palin utama mereka dapat berbagi mengenai cara-cara yang efektif untuk mengatasi rasa cemas, gelisah, dan terkadang depresi yang mereka rasakan. Dengan dilakukannya terapi konseling kelompok yang rutin seperti ini, maka akan memberikan banyak manfaat pada pendamping muda ini, yaitu akan dapat mengurangi ketegangan, kecemasan, bahkan simptom depresi yang mereka alami.

\section{SIMPULAN}

Situasi pandemi covid-19 ini memberikan dampak bagi proses pendampingan korban kekerasan pada perempuan dan anak yang dilakukan oleh pendamping muda P2TP2A Aceh Utara. Salah satu dampak yang paling signifikan adalah bertambahnya kecemasan para pendamping muda ini dalam melaksanakan pekerjaan mendampingi perempuan dan anak korban kekerasan. Kecemasan yang paling menonjol adalah 
cemas atau takut tertular virus yang sedang mewabah tersebut, karena para pendamping ini harus berhadapan dengan orang banyak ketika bekerja, dan harus berulangkali masuk rumah sakit untuk menemani korban melakukan proses pemeriksaan fisik. Mereka juga was-was berhadapan dengan klien yang terlihat sering tidak mematuhi protokol covid-19, seperti tidak menggunakan masker, tidak mencuci tangan, bersentuhan dengan orang lain, dan tidak menjaga jarak. Para pendamping ini juga cemas karena tidak mengetahui dengan jelas apakah klien mereka positif covid atau tidak, karena tidak ada pemeriksaan rapid test atau swab test pada klien. Program konseling kelompok pada pendamping muda ini dimaksudkan untuk mengurangi kecemasan yang dialami oleh para pendamping muda, dan diharapkan mereka menemukan teknik dan cara sendiri untuk mengatasi kecemasan yang mereka alami. Setelah dilakukan asesmen, psikoedukasi, dan tiga tahap konseling kelompok, ternyata hasil yang dicapai luar biasa. Para pendamping merasa bahagia dapat diikutsertakan dalam program konseling ini karena memberikan banyak manfaat bagi mereka. Diantaranya, mereka dapat berbagi pengalaman dan cerita dengan pendamping lainnya, mereka dapat melepaskan rasa sesak di dada akibat banyak sekali mendengarkan kisah-kisah hidup menyedihkan para perempuan korban kekerasan, dan yang paling utama mereka dapat berbagi mengenai cara-cara yang efektif untuk mengatasi rasa cemas, gelisah, dan terkadang depresi yang mereka rasakan. Kesimpulannya, dengan dilakukannya terapi konseling kelompok yang rutin seperti ini, maka akan memberikan banyak manfaat pada pendamping muda, yaitu dapat mengurangi ketegangan, kecemasan, bahkan simptom depresi yang mereka alami.

\section{DAFTAR PUSTAKA}

Dewi, K. S. (2012). Buku Ajar: Kesehatan Mental. Semarang: LPPM Universitas Diponegoro.

Permen PPPA RI. (2015). Nomor 6 Tentang Sistem Pemberdayaan Perempuan dan Perlindungan Anak. Jakarta: PPPA RI.

P2tp2a.acehprov.go.id. (2019). Diakses pada tanggal 29 Juni 2020, dari link https://p2tp2a.acehprov.go.id/index.php /news/index.

Ridlo, I. A. (2020). Pandemi Covid-19 dan tantangan kebijakan kesehatan mental di Indonesia. Jurnal Psikologi dan Kesehatan Mental, 5(2), hal.162-171. 